\title{
Grant applications swamp agency
}

Peer-review system for National Institutes of Health grants is stretched to its limits.

The US National Institutes of Health, already groaning under the weight of grant applications brought on by a $\$ 10.4$-billion economic stimulus package, is likely to be inundated with a second tidal wave of applications this autumn that would send success rates plummeting, agency officials predict.

The flood of applications for Challenge Grants, a new category created by the stimulus funds, means that the success rate will probably be less than $1 \%$. If scientists rejected for Challenge Grants this summer resubmit their applications for standard investigator-initiated 'R01' grants in the autumn, paylines - the percentage of fundable applications - will also bottom out, officials said at an 8 June meeting of the NIH's peer-review advisory committee.

"The NIH budget for 2010, unless there's another miracle, is a very small increase," said Story Landis, director of the National Institute of Neurological Disorders and Stroke in Bethesda, Maryland. "So if in fact all those grants come in, the payline will go to nothing."

"To the low single digits," interjected Antonio Scarpa, director of the agency's Center for Scientific Review. His back-of-the-envelope calculations project that the agency would receive 30,000 R01 proposals this autumn, many of them reincarnated Challenge Grants. Furthermore, he calculated that when the unsuccessful applications from that round are resubmitted yet again, the agency will face 25,000 review decisions in October 2010.

Reviewing at this magnitude "is not sustainable," Scarpa said. The agency is already reviewing more than 40,000 investigator-initiated applications; in a typical June review round, that figure would be 16,000 . The NIH normally uses around 8,000 reviewers; it is now up to about 30,000.

More than 21,000 applications have been submitted for Challenge Grants (see table).

Others at the advisory meeting said that the serial wave of applications is being unwisely encouraged by university deans of research. "We have been hearing that deans are telling people: 'If you don't get a Challenge Grant, you turn around and submit another research

\begin{tabular}{|c|c|c|c|c|}
\hline \multicolumn{5}{|l|}{ THE SURGE } \\
\hline Type of NIH grant & Due date & Size & $\begin{array}{l}\text { Number of applications } \\
\text { received, as of } 4 \text { June }\end{array}$ & $\begin{array}{l}\text { Total funds available } \\
\text { initially }\end{array}$ \\
\hline Challenge Grant & 27 April & $\begin{array}{l}\$ 1 \text { million ( } \$ 500,000 \\
\text { per year for two years) }\end{array}$ & About 21,000 & $\$ 200$ million \\
\hline $\begin{array}{l}\text { Grand } \\
\text { Opportunity } \\
\text { Grant }\end{array}$ & 5 June & $\begin{array}{l}\text { More than } \$ 500,000 \\
\text { per year for two years; } \\
\text { no maximum }\end{array}$ & 2,697 & $\begin{array}{l}\$ 200 \text { million by } \\
\text { September } 2010\end{array}$ \\
\hline $\begin{array}{l}\text { Competitive } \\
\text { revisions to } \\
\text { existing NIH } \\
\text { grants }\end{array}$ & 23 April & $\begin{array}{l}\text { No limit, but there is } \\
\text { a } \$ 100,000 \text { limit on } \\
\text { equipment purchases }\end{array}$ & 2,894 & $\$ 1$ billion \\
\hline $\begin{array}{l}\text { High-end } \\
\text { instrumentation } \\
\text { grants }\end{array}$ & 6 May & $\begin{array}{l}\text { Between } \$ 500,000 \text { and } \\
\$ 8 \text { million }\end{array}$ & 561 & $\$ 160$ million \\
\hline $\begin{array}{l}\text { Extramural } \\
\text { facilities } \\
\text { improvement } \\
\text { grants }\end{array}$ & $\begin{array}{l}6 \text { May; } \\
17 \text { June; } \\
17 \text { July }\end{array}$ & $\begin{array}{l}\text { Between } \$ 2 \text { million and } \\
\$ 15 \text { million }\end{array}$ & $\begin{array}{l}\text { Applications still } \\
\text { open }\end{array}$ & $\$ 1$ billion \\
\hline
\end{tabular}

project grant.' This is a really serious problem," said Louise Ramm, deputy director of NIH's National Center for Research Resources. "It's frightening."

Garret FitzGerald, chair of pharmacology at the University of Pennsylvania in Philadelphia, added: "Deans have been told they will be rewarded by the number of grants that go out

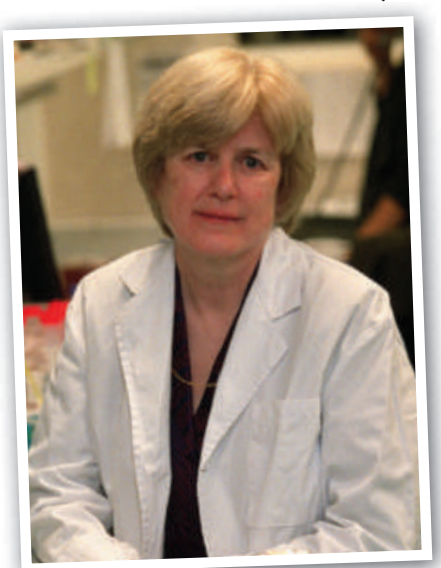

Mary-Claire King: problems ahead. the door. This is irresponsible behaviour."

At universities, "the sponsored-projects offices have been flooded by the number of grants going in. That flood is now becoming a tsunami," Mary-Claire King, a human geneticist at the University of Washington in Seattle, said last week. "They need an early-warning system."

The NIH is in the process of modelling the likely downstream impact of the stimulus spending. That is difficult to gauge at this point, acting NIH director Raynard Kington said last week, in part because it also depends on how much money Congress gives the agency in 2011 and beyond. Its budget for fiscal year 2009 is $\$ 30.3$ billion; last month, President Barack Obama proposed a \$443-million, or 1.4\%, increase for fiscal year 2010 .

The NIH, which is already in the middle of implementing changes to its peer-review system, has responded to the Challenge Grant flood by recruiting thousands of extra reviewers and adopting 'editorial board' reviews, which involve initial reviews by e-mail and final assessments by boards of highly accomplished scientists.

Among concerns voiced by Kington's advisers at a 4 June meeting is the potential burden imposed by new quarterly reporting requirements for the stimulus money. These have not come into effect yet, but are expected to do so by late summer. The Office of Management and Budget is setting up a reporting system to track the overall $\$ 787$ billion in stimulus money; reporting will be consistent across all federal agencies.

"All of us in the extramural world are concerned about what this reporting requirement is going to be and how we are going to manage it," said King. She implored Kington and his staff to adjust the government's template, once finalized, so that "an ordinary mortal scientist" can fill it out.

Kington said it is highly unlikely that the NIH would be able to modify a reporting template signed off by top administration officials as a universal requirement. But, he said, the stimulus money has launched a discussion about how the United States tracks the impact of its science funding. "That's going to be here to stay."

Meredith Wadman 